\title{
PENDIDIKAN KARAKTER ISLAMI ANAK USIA DINI DI PAUD SEURAMOE JAYA
}

\author{
Ismail Darimi \\ Universitas Islam Negeri Ar-Raniry Banda Aceh, Indonesia \\ Email: ismail.darimi@ar-raniry.ac.id \\ Orcid ld: 0000-0002-8280-7267
}

Article received: 27 Agustus 2018 Review process: 31 Agustus 2018

Article published:30 September 2018

\begin{abstract}
Giving a good example as an Islamic character to a child is the starting point of a child introduced to have a good personality so that he can become a righteous child. The role and figure of an educator or a teacher is a milestone in the formation of akhlaqul karimah for students. The process of formation of early childhood morality, namely: First, through qudwah, uswah (exemplary) teacher; Second, through ta'lim (teaching); Third, ta'wid (habituation); Fourth, Targhib / reward, motivation (giving motivation); Fifth, Tarhib / punishment, warning (giving threats and legal sanctions).
\end{abstract}

Keywords: education; Islamic character; child; early age

\begin{abstract}
Abstrak
Memberi teladan yang baik sebagaiman karakter islami pada anak merupakan titik awal anak dikenalkan untuk memiliki kepribadian baik sehingga dapat menjadi anak saleh. Peran dan figur dari seorang pendidik atau seorang guru menjadi tonggak dalam pembentukan karakter Islami (akhlaqul karimah) pada anak didik. Proses pembentukan akhlaqul karimah anak usia dini yakni: Pertama, melalui qudwah, uswah (keteladanan) guru; Kedua, melalui ta'lim (pengajaran); Ketiga, ta'wid (pembiasaan); Keempat, Targhib/reward, motivation (pemberian motivasi); Kelima, Tarhib/punishment, warning (pemberian ancaman dan sangsi hukum).
\end{abstract}

Kata Kunci: pendidikan; karakter islami; anak; usia dini

\section{PENDAHULUAN}

Kajian pendidikan karakter islami anak usia dini merupakan telaah proses pembentukan karakter Islami pada anak usia dini. Guru merupakan seorang pendidik yang dibebankan tugas padanya untuk membina dan membimbing peserta didik ke arah yang sesuai dengan aturan yang berlaku dalam kehidupan sehari-hari. Pengertian diatas diambil berdasarkan pendapat Muslicha, A. (2015), yakni "guru sebagai pendidik dan pengajar". 
dan pendapat Darimi, I. (2015) dimana "Guru menurut paradigma baru ini bukan hanya bertindak sebagai pengajar, tetapi juga sebagai pendidik, motivator, fasilitator, pembimbing dan evaluator proses belajar mengajar yaitu realisasi atau aktualisasi potensi-potensi manusia agar dapat mengimbangi kelemahan pokok yang dimilikinya."

Pembentukan karakter islami (akhlaqul karimah) pada anak usia dini, seorang guru harus memperlihatkan contoh teladan agar peserta didik lebih terkesan dan memiliki rasa kagum kepada gurunya, sehingga dengan sendirinya peserta didik tersebut akan terbiasa mempraktekkan kejujuran dalam kehidupannya, baik di lingkungan sekolah maupun di lingkungan keluarga dan masyarakat (Safriadi, 2015).

Guru merupakan profesi yang amat mulia, Islam sangat menghargai guru. Dalam Islam juga, tidak semua orang menjadi guru (Darimi, I. 2015). Artinya seseorang ingin menjadi guru selain harus memenuhi kualifikasi keilmuan dan akademis juga harus teruji akhlaknya. Seorang guru tidak selalu terpaku pada mengajarkan ilmu-ilmu pengetahuan, namun lebih penting pula membentuk karakter dan pribadi anak didiknya dengan akhlak dan ajaran-ajaran Islam. Guru bukan hanya sekedar pemberi ilmu pengetahuan kepada anak didiknya, tetapi merupakan sumber ilmu dan moral. Sehingga akan membentuk seluruh pribadi anak didiknya, menjadi manusia yang berkepribadian mulia.

Memberi teladan karakter islami pada anak merupakan titik awal anak dikenalkan untuk memiliki kepribadian baik sehingga dapat menjadi anak saleh. Dalam hal ini peran dan figur dari seorang pendidik atau seorang guru menjadi tonggak dalam pembentukan karakter islami (akhlaqul karimah) pada anak didik. Segala perbuatan dan tingkah laku pendidik atau guru akan ditiru oleh anak didiknya. Ibaratnya, seorang guru digugu dan ditiru segala tindakannya. Menjadi seorang guru tidak mudah karena selain mempunyai kompetensi akademik juga harus memiliki kepribadian yang mulia (Darimi, I. 2015). Karena kepribadian yang mulia tersebut merupakan salah satu persyaratan bagi seorang guru. Selain itu guru juga dipandang terhormat dan mempunyai status sosial yang tinggi dihadapan masyarakat. Sehingga semua tingkah laku dan kepribadian seorang guru akan dipandang dan dinilai oleh masyarakat. Guru harus selalu berkepribadian baik dimana pun dia berada.

Guru adalah orang yang sangat berpengaruh dalam proses pembelajaran (Darimi, I. 
2016). Guru harus betul-betul bisa membawa siswanya kepada tujuan yang ingin dicapai. Guru harus mampu mempengaruhi siswanya dalam hal positif atau baik. Berpandangan luas akan menunjukkan kewibawaan. Kewibawaan telah mengantarkan guru memiliki kesungguhan, kekuatan, terkesan dan berpengaruh (Sutisna, U. (2016). Setiap orang yang akan melaksanakan tugas sebagai seorang guru harus punya kepribadian yang baik. Guru merupakan tokoh yang akan ditiru dan diteladani." Dalam melaksanakan tugasnya sebagai pendidik, guru juga mau dan rela serta memecahkan berbagai masalah yang dihadapinya, terutama masalah yang langsung berhubungan dengan proses pembelajaran.

Permasalahan dalam penelitian ini dirumuskan bagaimana proses pembentukan karakter islami pada anak usia dini. Adapun tujuan penelitian yang hendak dicapai adalah memperoleh suatu temuan terkait pendidikan karakter islami pada anak usia dini. Penelitian ini diharapkan dapat memberikan sumbangan berupa penambahan khasanah pengetahuan mengenai langkah-langkah guru dalam upaya pembentukan akhlakul karimah pada usia dini di PAUD Seuramoe Jaya dan penelitian ini akan menjadi gambaran dan masukan bagi semua pihak, terkait dengan langkah-langkah guru dalam upaya pembentukan karakter islami pada anak usia dini.

\section{KAJIAN TEORITIK}

Hakikat pendidikan sebagai proses pemanusiawian manusia (humanisasi) sering tidak terwujud karena terjebak pada penghancuran nilai kemanusiaan (dehumnisasi). Hal ini merupakan akibat adanya perbedaan antara konsep dengan pelaksanaan dalam lembaga pendidikan. Kesenjangan ini mengakibatkan kegagalan pendidikan dalam mencapai misi sucinya untuk mengangkat harkat dan martabat manusia. Pendidikan belum berhasil memanusiawikan peserta didik. (Idris, S., \& Tabrani, Z. A. 2017)

Pembentukan karakter islami adalah mengiternalisasika nilai-nilai islami dalam jiwa anak. Saifulah Idris (2017) menyebutkan:

Internalisasi adalah penghayatan, pendalaman, penguasaan secara mendalam melalui suatu pembinaan, bimbingan dan sebagainya. Artinya, internalisasi merupakan proses yang mendalam untuk menghayati nilai-nilai yang didapatkan oleh peserta didik dipadukan dengan nilai-nilai pendidikan secara utuh yang sasarannya supaya menyatu dalam kepribadian peserta didik itu sendiri, sehingga menjadi satu karakter atau watak bagi 
peserta didik. Internalisasi juga merupakan sentral perubahan kepribadian yang merupakan dimensi kritis terhadap diri manusia yang di dalamnya memiliki makna kepribadian terhadap respons yang terjadi dalam proses pembentukan watak manusia.

Ada dua karakter utama orientasi pendidikan yang berkembang sejak abad pertengahan kini. Pertama, orientasi mencari kebenaran. Pendidikan dilakukan untuk mencari kebenaran sejati. ini merupakan orientasi pendidikan skolastik. Kedua, Orientasi pengabdian masyarakat, pendidikan diposisikan sebagai upaya penyejahteraan masyarakat. Pengabdian masyarakat juga bisa berarti pendidikan dilakukan hanya untuk kepentingan manusia, inilah akar visi humanisme yang tersirat dalam paradigma pendidikan ini. (Saifulah Idris, 2017)

Undang-Undang RI Nomor 20 tahun 2003 tentang Sistem Pendidikan Nasional pemerintah menyebutkan bahwa tujuan pendidikan adalah berkembangnya potensi peserta didik agar menjadi manusia yang beriman dan bertakwa kepada Tuhan Yang Maha Esa, berakhlak mulia, sehat, berilmu, cakap, kreatif, mandiri, menjadi warga negara yang demokrasi dan bertanggung jawab. (Syamsul Kurniawan, 2016: 40)

Adapun tujuan pendidikan karakter menurut beberapa ahli yaitu:

1. Tujuan pendidikan karakter menurut Mulyasa (2011: 20) yaitu untuk membentuk dan membangun pola pikir, sikap, dan perilaku peserta didik agar menjadi pribadi yang positif, berakhlak karimah, berjiwa luhur dan bertanggung jawab.

2. Menurut Dharma Kusuma tujuan pendidikan karakter adalah memfasilitasi penguatan dan pengembangan nilai-nilai tertentu sehingga terwujud dalam prilaku anak, baik ketika proses sekolah maupun setelah proses sekolah (setelah lulus dari sekolah). Tujuan kedua adalah mengoreksi prilaku peserta didik yang tidak bersesuaian dengan nilai-nilai yang dikembangkan oleh sekolah. Tujuan ini memiliki makna bahwa pendidikan karakter memiliki sasaran untuk meluruskan berbagai prilaku anak yang negatif menjadi positif. (Dharma Kusuma, 2012)

3. Menurut ahli pendidikan Darmiyanti Zuchdi dalam Mulyasa (2011: 20) memaknai watak 
atau karakter sebagai seperangkat sifat-sifat yang selalu dikagumi sebagai tanda kebaikan, kebajikan dan kematangan moral seseorang.

Berdasarkan penjelasan menurut para ahli diatas tentang tujuan pendidikan karakter maka dapat kita simpulkan bahwa tujuan dari pendidikan karakter adalah untuk membentuk watak, perilaku anak didik agar menjadi pribadi yang jujur, disiplin, bertanggung jawab, mandiri, kreatif, dan berakhlak karimah agar dapat diimplementasikan oleh peserta didik baik ketika dalam proses sekolah maupun setelah proses sekolah (setelah lulus dari sekolah).

Membangun karakter anak adalah sejak kecil, karena anak-anak akan melihat dan mengolah dalam fikirannya apa yang dia lihat. Sering pula kita lihat bahwa ketika anak berusia di bawah 2 tahun, televisipun mudah mempengaruhi watak mereka. Orang tua yang bertengkar didepan anak kacil akan menyebabkan anak kecil terbawa emosi dan menagis. Maka dari itu ibu haruslah memahami karakter apa saja yang ditanamkan kepada anaknya dari tindakan dan pengajaran dan pembiasaan yang dibangun dirumah (Elfendri, dkk, 2012: $32)$.

Dalam perspektif ilmu akhlak, karakter atau akhlak dapat dibedakan menjadi dua: karakter atau akhlak lahiriah dan karakter atau akhlak batiniah. Cara untuk menumbuhkan kualitas masing-masing karakter atau akhlak ini berbeda-beda. Peningkatan karakter atau akhlak terpuji lahiriah dapat dilakukan melalui:

1. Pendidikan dan pengetahuan seseorang, cara pandang seseorang akan bertambah luas, tentunya dengan mengenal lebih jauh akibat dari masing-masing (akhlak terpuji dan tercela). Semakin baik tingkat pendidikan dan pengetahuan seseorang, sehingga mampu lebih mengenali mana yang tepuji dan tercela.

2. Menaati dan mengikuti peraturan dan undang-undang yang ada di masyarakat dan negara. Bagi seorang muslim tentunya alkan mengikuti atturan yang digariskan Allah dan Sunnah Nabi Muhammad SAW.

3. Kebiasaan, akhlak terpuji dapat ditingkatkan melelui kehendak atau kegiatan baik yang dibiasakan. 
4. Memilih pergaulan yang baik, sebaik-baik pergaulan adalah berteman dengan para ulama (orang beriman) dan ilmuwan (intelektual).

5. Melalui perjuangan dan usaha. Menurut Hamka bahwa akhlak terpuji, tidak timbul kalau tidak dari keutamaan sedangkan keutamaan tercapai melalui perjuangan. (Zubaedi, 2011)

Sekolah merupakan Lembaga formal yang secara sistematis melaksanakan program bimbingan pengajaran, atau pelatihan dalam rangka membantu para siswa agar mampu mengembangkan potensinya secara optimal, baik yang menyangkut aspek moral-spirituals, intelektual, emosional, sosial, maupun fisik-psikomotoriknya. (Syamsu Yusuf, 2012).

Sekolah juga berperan dalam pembentukan karakter Anak. Sebagai lembaga pendidikan, sekolah menanamkan karakter yang positif kepada anak-anak. Sekolah memiliki misi tertentu dalam membentuk manusia yang cerdas, terampil, dan berakhlak mulia sesuai aturan yang berlaku.

Pendidikan karakter mengemban misi untuk mengembangkan watak-watakdasar yang seharusnya dimiliki oleh peserta didik. Penghargaan (respect) dan tanggung jawab (responsibility) merupakan dua nilai moralpokok yang harrus diajarkan oleh sekolah. Nilainilai moral yang lain adalah kejujuran, keadilan, toleransi, kebijaksanaan, kedisiplinan diri, suka menolong, rasa kasihan, kerja sama, keteguhan hati, dan sekumpulan nilai-nilai demokrasi.

Pendidikan karakter dilakukan melalui pendidikan nilai-nilai atau kebajikan yang menjadi nilai dasar karakter bangsa. Kebajikan yang menjadi atribut suatu karakter pada dasarnya adalah nilai. Oleh karena itu, pendidikan karakter pada dasarnya adalah penegembangan nilai-nilai yang berasal dari pandangan hidup atau ideologi bangsa Indonesia, agama, budaya, dan nilai-nilai yang terumuskan dalam tujuan pendidikan nasional. (Zubaedi, 2011)

Nilai-nilai yang dikembangkan dalam pendidikan karakter di Indonesia diindetifikasi berasal dari empat sumber. Pertama, agama. Masyarakat Indonesia merupakan masyarakat beragama. Oleh karena itu, kehidupan individu, masyarakat dan bangsa selalu didasari pada ajaran agama dan kepercayaannya. Kedua, Pancasila. Negara Kesatuan Republik Indonesia ditegakkan atas prinsip-prinsip kehidupan kebangsaan dan kenegaraan yang disebut 
Pancasila. Ketiga, budaya. Sebagai suatu kebenaran bahwa tidak ada manusia yang hidup bermasyarakat yang tidak didasari nilai-nilai budaya yang diakui masyarakat tersebut. Nilai budaya ini dijadikan dasar dalam pemberian makna terhadap suatu konsep dan arti dalam komunikasi antar anggota masyarakat tersebut. Keempat, tujuan pendidikan nasional,Undang-Undang Republik Indonesia Nomor 20 Tahun 2003 tentang Sistem Pendidikan Nasional (UU Sisdikas) merumuskan fungsi dan tujuan pendidikan nasioanalyang harus digunakan dalam mengembangkan upaya pendidikan di Indonesia.

Proses Pembentukan karakter islami (Akhlaqul Karimah) Anak Usia Dini.

1. keteladanan $(Q u d w a h)$ guru yang biasa memberikan keteladanan mengenai perilaku baik, maka biasanya akan ditiru oleh anak-anaknya dan muridnya dalam mengembangkan pola perilaku mereka.

2. Pengajaran (ta'lim). Misalnya dengan, mengajarkan empati dengan sifat disiplin. Anak jangan dibikin takut kepada orang tua atau guru, melainkan ditanamkan sifat hormat dan segan. Sebab jika hanya karena rasa takut, anak cenderung hanya berperilaku baik ketika ada orang tua atau gurunya. Namun begitu keluar dari rumah atau sekolah dan orang tua atau gurunya tidak mengetahui, maka ia akan berani melakukan penyimpangan moral.

3. Pembiasaan ( $t a$ 'wid). Melatih anak dengan perbuatan terpuji (karakter islami) yang bisa membentuk kepribadiannya. Sebagai contoh anak dibiasakan berdoa sebelum dan sesudah makan.

4. Pemberian motivasi (Targhib), memberikan motivasi baik berupa pujian atau hadiah tertentu, akan menjadikan salah satu latihan positif dalam proses pembentukan akhlak terutama ketika ia masih kecil.

5. Pemberian ancaman dan sangsi hukum (Tarhib). Dalam rangka proses pembentukan akhlak kadang diperlukan ancaman, sehingga anak tidak bersifat seenaknya. Dengan begitu ketika anak mau melanggar norma tertentu akan merasa enggan, apalagi jika hukumannya cukup berat. (Abdul Mustaqib, 2013)

\section{METODOLOGI}

Jenis Penelitian ini adalah penelitian kualitatif. Subjek penelitian ini guru PAUD Seuramoe Jaya. Adapun teknik penelitian ini dapat dilakukan dengan cara observasi, Dalam penelitian ini, penulis akan mengamati bagaimana pendidikan karakter islami pada 
anak usia dini. Selanjutnya peneliti juga menggunakan teknik Wawancara. Teknik analisis data pada penelitian ini adalah sesuai dengan teknik pengumpulan data. Untuk analisis data wawancara peneliti melalui tahapan reduksi data. Selanjutnya tahap penyajikan data dan penarikan kesimpulan (Walidin, W., \& Idris, S. 2015).

\section{HASIL DAN PEMBAHASAN}

Sebagai seorang muslim, pembentukan karakter Islami sangat dibutuhkan dalam proses pembelajaran untuk membentuk karakter pribadi anak didik, apalagi anak usia dini yang sanagt mudah terpengaruh oleh keadaan lingkungan sekitar. Dalam usia anak-anak ini sangat diperlukan pendidikan dan bimbingan akhlak karena pada masa ini anak lebih mudah diarahkan sehingga anak menjadi anak yang shaleh. Pada PAUD Seuramoe Jaya ini anak diberikan bimbingan akhlak melalui pembelajaran dan bimbingan sehari-hari.

Wawancara dengan guru yang merupakan kepala PAUD Seuramoe Jaya menghasilkan temuan yang dapat peneliti simpulkan adalah karena masih usia kanak-kanak, yang dapat diterapkan ada beberapa karakter islami pada anak usia dini seperti mereka mengucapkan salam ketika berangkat kesekolah saat pamitan kepada orangtua. Kemudian diajarkan juga untuk tidak berbohong dengan metode pembiasaan dalam interaksi seharihari disekolah, baik interaksi dengan guru, sesama teman bahkan dengan orang tua sekalipun (Guru PAUD Seuramoe Jaya, 2018). Hal ini juga didukung oleh wawancara dengan guru PAUD, yakni langkah-langkah yang dilakukan dalam pembentukan karakter islami pada anak adalah:

"Ketika anak-anak menerima sesuatu dari orang lain baik hadiah maupun lainnya selalu diajarkan untuk mengucapkan terima kasih, meminta ma'af jika salah dan mema'afkan bila ada yang minta maaf. Pendidikan karakter islami yang lain juga dilakukan dengan mengaktualisasikan cuci tangan sebelum makan, ketika makan dengan duduk dan tidak boleh bersuara, berjabat tanan dengan guru, orang tua serta teman jika bertemu, tidak bersuara dan berkata-kata keras jika berbicara” (Guru PAUD Seuramoe Jaya, 2018).

Hal demikian sejalan dengan pendapat Abdul Mustaqib (2013), dimana proses Pembentukan karakter islami (Akhlaqul Karimah) Anak Usia Dini. 
1. Keteladanan (Qudwah) guru yang biasa memberikan keteladanan mengenai perilaku baik, maka biasanya akan ditiru oleh anak-anaknya dan muridnya dalam mengembangkan pola perilaku mereka.

2. Pengajaran (ta'lim). Misalnya dengan, mengajarkan empati dengan sifat disiplin. Anak jangan dibikin takut kepada orang tua atau guru, melainkan ditanamkan sifat hormat dan segan. Sebab jika hanya karena rasa takut, anak cenderung hanya berperilaku baik ketika ada orang tua atau gurunya. Namun begitu keluar dari rumah atau sekolah dan orang tua atau gurunya tidak mengetahui, maka ia akan berani melakukan penyimpangan moral.

3. Pembiasaan ( $t a$ 'wid). Melatih anak dengan perbuatan terpuji (karakter islami) yang bisa membentuk kepribadiannya. Sebagai contoh anak dibiasakan berdoa sebelum dan sesudah makan.

4. Pemberian motivasi (Targhib), memberikan motivasi baik berupa pujian atau hadiah tertentu, akan menjadikan salah satu latihan positif dalam proses pembentukan akhlak terutama ketika ia masih kecil.

5. Pemberian ancaman dan sangsi hukum (Tarhib). Dalam rangka proses pembentukan akhlak kadang diperlukan ancaman, sehingga anak tidak bersifat seenaknya. Dengan begitu ketika anak mau melanggar norma tertentu akan merasa enggan, apalagi jika hukumannya cukup berat.

Pada pembentukan karakter islami ini guru lebih cenderung menekankan pada pembentukan dan bimbingan bukan semata pengajaran. Karena definisi pengajaran disini hanya sebatas menyampaikan ilmu atau penerapanya. Selain itu pembentukan akhlak ini cenderung menekankan pada kemandirian belajar (aktif learning), kerja sama dalam bersosialisasi dan saling menghargai.

Pembentukan akhlak disini guru diharapkan memberi ilmu (pengajaran), misalnya apa itu kejujuran, untuk apa harus jujur sampai anak mengerti apa yang disampaikan guru. Sehingga anak merasa itu penting dan akan tertanam dalam jiwa anak tentang yang disampaikan guru. Karena pada masa usia dini merupakan masa peletakan dasar atau pondasi awal bagi pertumbuhan dan perkembangan anak. Apa yang diterima anak pada masa usia dini, apakah itu makanan, minuman, serta stimulasi dari lingkungannya memberi pengaruh sangat besar pada pertumbuhan dan perkembangan anak pada masa itu dan pada 
masa selanjutnya.

Usia dini merupakan masa perkembangan dan pertumbuhan yang sangat menentukan anak di masa yang akan datang, sekaligus periode sangat kritis yang menentukan tahap pertumbuhan dan perkembangan anak selanjutnya. Dalam pembentukan akhlak ini, diharapkan anak mampu dan mandiri serta dapat bersosialisasi yang baik terhadap siapapun terlebih pada teman bermain. Anak diharapkan mampu berkomunikasi, beradaptasi, berintelegensi, berakhlakul karimah.

Agar anak mampu berkomunikasi dan bersikap baik diperlukan pembentukan akhlak sehingga anak dapat berbicara baik dan jujur. Seorang anak apabila memiliki akhlak yang baik dan jujur mudah beradaptasi dengan lingkungan. Karena anak mampu menyesuaikan dengan lingkungan terutama terhadap teman-teman bermainnya. Berintelegensi, anak diharapkan tidak hanya pandai dalam pembelajaran tetapi juga dalam hal akhlak dan budi pekerti agar anak mudah bersosialisasi. Sejak usia dini anak diberikan pembentukan akhlak yang baik agar dalam kehidupannya kelak dapat berakhlakul karimah terutama memiliki sifat kejujuran.

Pembentukan akhlak sangat penting terutama dalam pendidikan anak usia dini. Karena pada masa inilah anak diibaratkan seperti kertas putih. Maka yang memberikan warna atau tulisan baik atau buruk adalah pendidik, apabila anak berada di lingkungan pendidikan. Sehingga semua tingkah laku dan perbuatan pendidik akan ditiru anak didik. Oleh sebab itu, PAUD Seuramoe Jaya dalam pembentukan akhlakul karimah dilakukan dengan cara membiasakan dan menasehati saja, seperti mengucapkan salam ketika berangkat kesekolah, tidak berbohong, tidak mengejek teman, tidak berantem sesama teman, tidak menyoraki teman kalau jawabannya salah, berkata sopan dan santun dalam bertindak, ramah dengan teman, tidak berebut dalam bermain, saling berbagi, jika diberi mengucapkan terima kasih, mau minta ma'af dan mema'afkan, mencuci tanan sebelum makan, jika makan dengan duduk rapi dan tidak bersuara.

Dalam proses pembentukan akhlakul karimah pada usia dini, guru PAUD Seuramoe Jaya ada yang menggunakan media. Media akan memberikan dampak yang baik terhadap suksesnya sebuah pembelajaran. Oleh karena itu, ada beberapa media yang digunakan oleh guru PAUD Seuramoe Jaya dalam pembentukan akhlakul karimah pada anak diantaranya 
ialah: video, gambar-gambar yang berkaitan dengan akhlakul karimah.

Berdasarkan hasil wawancara dan observasi, guru PAUD Seuramoe Jaya dalam pendidikan karakter islami dilakukan dengan cara membiasakan (pembiasaan) dan menasehati saja, tetapi tidak memberikan ilmu (pengajaran) atau wawasan tentang hal yang menjadi materi nasehat dan larangan dari apa yang ingin dibiasakan tersebut. Seharusnya guru mengembangkan wawasan keilmuan menyangkut materi didik, sesuai dengan tingkat kemampuan anak dalam menerima yang disampaikan guru.

Pembentukan akhlak ini diberikan sejak anak usia dini dengan harapan agar putraputrinya menjadi anak yang berakhlak mulia, bekerja keras, saling membantu, menghargai teman, disiplin, dan jujur. Namun sejalan dengan hal ini sangat dibutuhkan dukungan dari orang tua serta lingkungan masyarakat sekitar agar pembentukan Akhlakul Karimah dapat berhasil secara maksimal. Oleh sebab itu diperlukan adanya kerja sama yang baik antara masing-masing pihak tersebut.

Setiap lembaga pendidikan pasti mempunyai hambatan dalam proses pembelajaan. Demikian juga halnya PAUD Seuramoe Jaya juga mengalami hambatan dalam pembentukan akhlakul karimah pada anak. Hambatan tersebut antara lain adalah guru kurang memahami karakter dan kemampuan dalam menerima materi pembelajaran dari masing-masing anak, bagi pendidik baru harus dapat dengan cepat menyesuaikan diri dengan keadaan siswa atau anak didik.

Guru harus dapat memahami karakter masing-masing anak, karena kita tahu bahwasannya anak memiliki karakter berbeda-beda sesuai dengan sifat pembawaannya. Jika anak memiliki karakter dan pribadi yang baik maka anak tersebut akan selalu patuh terhadap materi pelajaran yang diterima di sekolah.

Selain itu juga terdapat hambatan lain seperti guru kurang kreatifitas dalam mengajar, kurang ilmu tentang bagaimana pendidikan usia dini semestinya berlangsung. Hal inilah yang menjadi penghambat dalam proses pembelajaran di PAUD Seuramoe Jaya.

Meskipun demikian masih terdapat banyak hambatan yang dihadapi, namun pihak sekolah tetap berusaha semaksimal mungkin demi kelancaran proses pembelajaran. Hal itu dilakukan untuk memberikan pendidikan yang terbaik untuk anak didik sehingga dalam proses pembelajaran ini akan berhasil sesuai dengan harapan bersama. 
Suatu tantangan dalam proses pembelajaran selalu dialami oleh pihak lembaga pendidikan. Namun, tantangan tersebut dapat diatasi tergantung seberapa cakap pihak lembaga pendidikan tersebut dalam menyikapi dan mencari solusi yang terbaik agar proses pembelajaran berlangsung semestinya.

Demikian juga halnya di PAUD Seuramoe Jaya juga mengalami tantangan dalam pembentukan akhlakul karimah pada anak, seperti hasil wawancara dengan kepala PAUD mengatakan bahwa: "Ya tentunya kami sebagai pendidik kami harus memiliki kesabaran tinggi karena anak-anak memiliki sifat beraneka ragam, ada anak yang sering mengulang kesalahan yang sama walaupun kita sudah menasehati agar tidak mengulang kesalahan tersebut..." (Guru PAUD Seuramoe Jaya, 2018).

Data ini juga didukung oleh hasil wawancara dengan guru PAUD, dikatakan bahwa: “... Tantangan yang kami hadapi antara lain kebiasaan anak di sekolah selalu patuh tetapi ketika di rumah tidak mau menerapkan yang diajarkan di sekolah tetapi itu sebagian kecil dari anak selain itu juga ada anak yang memiliki disiplin tinggi" (Guru PAUD Seuramoe Jaya, 2018).

Tantangan tersebut dapat terjadi disebabkan adanya faktor yang mendorong anak tidak patuh antara lain seperti masalah kefakiran, pertengkaran dan pertikaian yang terjadi pada orang tua dan orang tua yang tidak memperhatikan pendidikan anaknya. Oleh karena adanya anak tidak patuh menyebabkan terkendalanya proses pembelajaran. Faktor orang tua yang tidak memperhatikan pendidikan anak merupakan sesuatu yang menjadi masalah serius. Karena antara orang tua dan pihak sekolah harus mampu bekerja sama dengan baik dalam proses pendidikan. Tantangan inilah yang membuat guru harus punya kesabaran dan kemampuan dalam menghadapi anak.

Dari data di atas juga didukung oleh hasil observasi penulis bahwa tantangan yang yang dihadapi oleh guru PAUD Seuramoe Jaya adalah ketika mengajar anak kadang sulit dikendalikan untuk tertib, tetapi ada juga anak yang disiplin tanpa diperintah selalu menjalankan tata tertib yang ada, yang paling sulit adalah mengatasi anak yang cengeng ketika anak bermain dan bertengkar dengan temannya".

Dari hasil wawancara dan observasi penulis dapat disimpulkan bahwa tantangantantangan yang terjadi dalam proses pembentukan Akhlakul Karimah di PAUD Seuramoe 
Jaya adalah anak sering mengulangi kesalahan, kebiasaan anak di sekolah selalu patuh tetapi ketika di rumah tidak mau menerapkan dan ketika mengajar anak kadang sulit dikendalikan untuk tertib. Kebiasaan anak yang tidak baik itu bisa diubah dengan cara menasehati, membiasakan dan memberi ilmu tentang kebiasaan yang dilakukan tersebut. Namun tantangan-tantangan tersebut minim mungkin bisa diatasi meskipun tidak dapat sepenuhnya sempurna dalam mengatasi tantangan tersebut. Tetapi setidaknya dapat mengurangi sehingga proses pembelajaran berjalan dengan sempurna dan tercapai tujuannya.

Berdasarkan hasil wawancara dengan Ibu Safrina mengatakan bahwa dalam menghadapi tantangan tersebut guru diharapkan memiliki kesabaran yang tinggi dalam mendidik anak, menegur dan menasehati ketika anak berbuat salah.

Disamping itu, hasil wawancara dengan guru PAUD, beliau mengatakan bahwa: "Kalau menghadapi tantangan kami sudah biasa dengan berbagai variasi, salah satunya dengan kesabaran dan kami selalu usahakan untuk mereka supaya lebih baik lagi kedepannya." (Guru PAUD Seuramoe Jaya, 2018).

Dari hasil wawancara di atas dapat disimpulkan bahwa seorang guru harus memiliki sifat kesabaran, kedisiplinan, dan keikhlasan dalam mendidik. Disamping itu orangtua juga harus ikut serta dalam mendidik anak.

\section{SIMPULAN}

Karakter Islami dapat dibentuk pada Anak Usia Dini melalui keteladanan, pengajaran, pembiasaan, pemberian motivasi dan pemberian ancaman dan sangsi hukum. Asas islami yang diterapkan oleh Rasulullah dalam pendidikan yaitu mengulang-ulang (supaya mudah dipahami), sedikit demi sedikit (supaya mudah dipahami), memilih yang paling ringan, mudah dan luwes (fleksibel), dalam kondisi segar (supaya khusyuk dan konsentrasi), memilih waktu yang tepat (untuk menyampaikan nasihat/ materi pendidikan), memperhatikan bakat (kodrat atau potensi anak/ peserta didik), mengikuti kecenderungan anak/ peserta didik, mengetahui tingkat kemampuan anak/ peserta didik, berjenjang (sesuai tahapan usia anak / peserta didik, stabil dan berkelanjutan ( dalam melaksanakan ilmu/ beramal) dan menyesuaikan perlakuan dengan martabat (kedudukan atau keadaanya).

Langkah-langkah yang dilakukan dalam penbentukan akhlaqul karimah anak antara 
lain apabila dikasih sesuatu atau menerima sesuatu selalu mengucapkan terima kasih, meminta ma'af jika salah dan saling mema'afkan, cuci tangan sebelum makan, ketika makan dengan duduk dan tidak boleh bersuara, berjabat tanan dengan guru, orang tua serta teman jika bertemu, tidak bersuara dan berkata-kata keras jika berbicara".

Pembentukan akhlak disini guru diharapkan memberi ilmu (pengajaran), misalnya apa itu kejujuran, untuk apa harus jujur sampai anak mengerti apa yang disampaikan guru. Sehingga anak merasa itu penting dan akan tertanam dalam jiwa anak tentang yang disampaikan guru. Karena pada masa usia dini merupakan masa peletakan dasar atau pondasi awal bagi pertumbuhan dan perkembangan anak.

Pembentukan akhlak ini diberikan sejak anak usia dini dengan harapan agar putraputrinya menjadi anak yang berakhlak mulia, bekerja keras, saling membantu, menghargai teman, disiplin, dan jujur. Namun sejalan dengan hal ini sangat dibutuhkan dukungan dari orang tua serta lingkungan masyarakat sekitar agar pembentukan Akhlakul Karimah dapat berhasil secara maksimal. Oleh sebab itu diperlukan adanya kerja sama yang baik antara masing-masing pihak tersebut.

\section{DAFTAR PUSTAKA}

Abdul Mustaqib, (2013), Akhlak Tasawuf: Lelaku Suci Menuju Revolusi Hati. Yogyakarta: Kaukaba Dibantara.

Darimi, I. (2015). Peningkatan Kompetensi Pedagogik Guru PAI dalam Pembelajaran. Jurnal MUDARRISUNA: Media Kajian Pendidikan Agama Islam, 5(2), 309324.

Darimi, I. (2016). Diagnosis Kesulitan Belajar Siswa Dalam Pembelajaran Aktif di Sekolah. JURNAL EDUKASI: Jurnal Bimbingan Konseling, 2(1), 30-43.

Dharma Kusuma, (2012), Pendidikan Karakter, Bandung: Remaja Rosdakarya.

Elfendri, dkk, (2012), Pendidikan Karakter Kerangka, Metode, dan Aplikasi untuk pendidik dan Profesional, Jakarta: Baduose.

Idris, S. (2017). Internalisasi Nilai dalam Pendidikan (Konsep dan Kerangka Pembelajaran dalam Pendidikan Islam). Yogyakarta: Darussalam Publishing.

Idris, S., \& Tabrani, Z. A. (2017). Realitas Konsep Pendidikan Humanisme dalam Konteks Pendidikan Islam. Jurnal Edukasi: Jurnal Bimbingan Konseling, 3(1), 96-113.

Imam Nawawi, (1999) Riyadush Shalihin, Jakarta: Pustaka Amani. 
Mulyasa, (2011), Manajemen Pendidikan Karakter, Jakarta: Bumi Aksara.

Muslicha, A. (2015). Metode Pengajaran Dalam Pendidikan Lingkungan Hidup Pada Siswa Sekolah Dasar (Studi Pada Sekolah Adiwiyata di DKI Jakarta). Jurnal Pendidikan, 16(2), 110-126.

Safriadi, S., Darimi, I., \& Siswanto, I. (2015). Strategi Pembinaan Religiusitas Anak dalam Keluarga. TAKAMMUL: Jurnal Studi Gender dan Islam serta Perlindungan Anak, 4(2), 1-11.

Sormin, D. (2016). Kompetensi Guru dalam Melaksanakan dan Mengelola Proses Belajar Mengajar di Pondok Pesantren Darul Mursyidi Desa Sialogo Tapanuli Selatan. FITRAH: Jurnal Kajian Ilmu-ilmu Keislaman, 2(1), 117130.

Sutisna, U. (2016). Pengaruh Kewibawaan Guru PAI Terhadap Motivasi Belajar Siswa SMK Al Kautsar. Faktor Jurnal Ilmiah Kependidikan, 3(2), 172-184.

Syamsu Yusuf, (2012) Perkembangan Peserta Didik, Jakarta, RajaGrafindoPrsada.

Syamsul Kurniawan, (2016) Pendidikan Karakter Konsepsi dan Implementasinya secara Terpadu Di Lingkungan Keluarga, Sekolah, Perguruan Tinggi dan Masyarakat, Yogyakarta: Ar-Ruzz Media.

Walidin, W., \& Idris, S. (2015). Metodologi Penelitian Kualitatif \& Grounded Theory.

Zubaedi, (2011). Desain Pendidikan Karakter Konsepsi dan Aplikasi dalam Lembaga Pendidikan, Jakarta: Kencana $\mathrm{P}$ 